\title{
An empirical study on the efficiency of bank innovation in the context of internet financial development Fan Yang ${ }^{*}$, Yong Qi \\ School of Economic\& Management, Nanjing University of Science\& Technology \\ *Corresponding author: Yang Fan,postgraduate,635403620@qq.com
}

\begin{abstract}
:
Recently, the rapid development of Internet finance has influenced the traditional financial model in many ways. As an emerging financial mode, it provides customers with a wider range of multiple financial services, but also has an impact on the commercial banks operating efficiency and innovation efficiency. In order to explore the impact of Internet finance on the innovation efficiency of commercial banks, this paper analyses the data of 14 commercial banks in China from 2009 to 2015. First, the BCC model is used to measure the innovation efficiency of commercial banks. Then the Malmquist index of commercial banks is measured and analysed dynamically. Finally, the Tobit model based on panel data is established for regression analysis. Put forward the conclusions of commercial banks which accord to the empirical analysis to deal with the impact of Internet financial countermeasures and suggestions.
\end{abstract}

Key words: Internet finance; commercial bank; innovation efficiency; financial innovation

\section{Introduction}

Since 2013, P2P platform has developed rapidly, the financing platform began to start, some banks, brokers also restructure the business model based on the Internet to accelerate the construction of innovative platform online. The development of Internet finance comes into the high-speed development stage. Commercial banking industry, as one of the three pillars of China's financial industry, is an important subject in the national economic system. In this context, this paper will explore the impact of Internet financial development on the efficiency of commercial banks innovation, which is of great significance for commercial banks to respond Internet finance impact.

Economist Sipler argues that financial innovation is the most positive for financial institutions that seek to maximize profits ${ }^{1}$. The Economist William Slpa argues that innovation is the product of economic impetus, and in financial activity, occasional observations suggest that most financial results stem from financial stimulus ${ }^{2}$. On the basis of MOA theory and text analysis method, Li Wenliang explores the relationship between Internet finance and commercial bank's innovation performance ${ }^{3}$.TAN Zhengxun uses the SBM model considering both nonperforming loans and slack variables to measure the efficiency of China's commercial banks ${ }^{4}$. XIANG XiaoDong combines the idea of network DEA and weight balance cross efficiency and constructs the cross efficiency evaluation model of each subsystem and chain system of commercial banks ${ }^{5}$. WANG JianKang conducts a comparative 
study of the similarities and differences between Internet financial products and commercial banks $^{6}$. HAN HongWen conducted an analysis of the relationship between Internet Finance and Commercial Banks from the Perspective of Dualism ${ }^{7}$.

Through the combing of the existing literatures, it is found that there are few scholars who study quantitative research on the development of Internet influence the innovation efficiency of commercial banks. This paper will focus on the innovation efficiency of commercial banks and the impact of Internet financial development on the innovation efficiency of commercial banks.

\section{Evaluation of innovation efficiency of commercial banks}

\subsection{Innovative input-output indicators}

Based on the actual situation of Chinese commercial banks and the availability of data, this paper chooses fixed assets, intangible assets, employees and management fees as inputs for innovation efficiency evaluation, and the intermediary business income is used as a measure of the efficiency of commercial banks outputs.

\subsection{Static analysis of innovation efficiency based on BCC model}

This paper uses Deap 2.1 software to calculate the efficiency of 14 sample banks, as shown in Table 1.

Table 1- 2009-2015 Comprehensive Innovation Efficiency Evaluation Results

Of Chinese 14 commercial banks

\begin{tabular}{lccccccccc}
\hline Banks & 2009 & 2010 & 2011 & 2012 & 2013 & 2014 & 2015 & Average & Rank \\
\hline Bank of Shanghai & 0.34 & 0.34 & 0.17 & 0.48 & 0.53 & 0.59 & 0.79 & 0.46 & 12 \\
Bank of Jiangsu & 0.27 & 0.27 & 0.26 & 0.45 & 0.42 & 0.36 & 0.40 & 0.35 & 14 \\
Bank of Nanjing & 0.79 & 0.79 & 0.22 & 0.78 & 0.57 & 0.68 & 0.71 & 0.65 & 9 \\
Bank of Ningbo & 0.57 & 0.57 & 0.51 & 0.59 & 0.57 & 0.42 & 0.56 & 0.54 & 10 \\
Bank of Hangzhou & 0.52 & 0.52 & 0.42 & 0.60 & 0.36 & 0.59 & 0.37 & 0.48 & 11 \\
Bank of Jiujiang & 0.43 & 0.43 & 1.00 & 0.53 & 0.42 & 0.58 & 0.18 & 0.51 & 8 \\
Bank of China & 1.00 & 1.00 & 0.45 & 1.00 & 0.99 & 0.80 & 0.88 & 0.87 & 5 \\
Agricultural Bank & 0.43 & 0.43 & 0.23 & 0.62 & 0.61 & 0.47 & 0.44 & 0.46 & 13 \\
Construction Bank & 1.00 & 1.00 & 0.51 & 1.00 & 1.00 & 1.00 & 1.00 & 0.93 & 3 \\
Guangfa Bank & 0.61 & 0.61 & 0.41 & 0.87 & 0.73 & 0.77 & 1.00 & 0.71 & 7 \\
CITIC Bank & 0.61 & 0.61 & 0.45 & 0.90 & 0.84 & 0.94 & 1.00 & 0.76 & 6 \\
Industrial Bank & 1.00 & 1.00 & 0.75 & 1.00 & 1.00 & 1.00 & 1.00 & 0.96 & 2 \\
Minsheng Bank & 1.00 & 1.00 & 0.83 & 1.00 & 1.00 & 0.95 & 1.00 & 0.97 & 1 \\
Merchants Bank & 0.81 & 0.81 & 0.55 & 1.00 & 0.99 & 1.00 & 1.00 & 0.88 & 4 \\
Average & 0.67 & 0.67 & 0.48 & 0.77 & 0.72 & 0.72 & 0.74 & 0.68 & \\
\hline
\end{tabular}


(1)It can be seen from Table 1 that the average innovation efficiency of China's 14 commercial banks in 2009-2015 is 0.68, indicating that Chinese commercial banks not effective, and the innovation efficiency of commercial banks in China needs to be improved. To 14 banks horizontal comparison, seven banks' innovation efficiency are over the average. MinSheng Bank average innovation efficiency is of 0.97, living in the first place, which is in a high efficiency state.

(2)From the analysis of time series, the average difference of the banks in the 2009-2015 is more obvious. For Bank of China, Construction Bank, MinSheng Bank, Industrial Bank, China Merchants Bank, the average efficiency of innovation are greater than 0.8, are highly innovative and efficient banks. For CITIC Bank, GF Bank, Ningbo Bank, Bank of Nanjing and Hangzhou Bank, the average efficiency of innovation is between 0.6-0.8, are relatively high efficiency and efficiency areas. Bank of Shanghai, Jiangsu Bank, Agricultural Bank and Jiujiang Bank are low innovation efficiency banks whose innovation efficiency value is less than 0.6.

(3)From the analysis of the bank type, the average efficiency of the joint-stock commercial banks is the highest (0.86), the state-owned commercial banks are the second, and the commercial banks have the lowest efficiency (the innovation efficiency is only 0.50).

Table 2- 2009-2015 Pure Innovation Efficiency Evaluation Results Of Chinese 14 commercial banks

\begin{tabular}{|c|c|c|c|c|c|c|c|c|c|}
\hline Banks & 2009 & 2010 & 2011 & 2012 & 2013 & 2014 & 2015 & Average & Rank \\
\hline Bank of Shanghai & 0.45 & 0.34 & 0.21 & 0.53 & 0.67 & 0.81 & 1.00 & 0.57 & 13 \\
\hline Bank of Jiangsu & 0.42 & 0.38 & 0.28 & 0.50 & 0.50 & 0.48 & 0.55 & 0.44 & 14 \\
\hline Bank of Nanjing & 1.00 & 0.81 & 0.30 & 0.90 & 0.83 & 0.94 & 1.00 & 0.83 & 10 \\
\hline Bank of Ningbo & 1.00 & 0.94 & 0.54 & 0.70 & 0.80 & 0.66 & 0.81 & 0.78 & 9 \\
\hline Bank of Hangzhou & 1.00 & 0.56 & 0.69 & 1.00 & 0.81 & 1.00 & 1.00 & 0.87 & 8 \\
\hline Bank of Jiujiang & 1.00 & 1.00 & 1.00 & 1.00 & 1.00 & 1.00 & 1.00 & 1.00 & 1 \\
\hline Bank of China & 1.00 & 1.00 & 1.00 & 1.00 & 1.00 & 1.00 & 1.00 & 1.00 & 1 \\
\hline Agricultural Bank & 0.43 & 0.59 & 0.63 & 0.62 & 0.63 & 0.56 & 0.51 & 0.57 & 12 \\
\hline Construction Bank & 1.00 & 1.00 & 1.00 & 1.00 & 1.00 & 1.00 & 1.00 & 1.00 & 1 \\
\hline Guangfa Bank & 0.70 & 0.75 & 0.57 & 0.89 & 0.76 & 0.81 & 1.00 & 0.78 & 10 \\
\hline CITIC Bank & 0.62 & 0.94 & 0.82 & 0.90 & 0.85 & 0.95 & 1.00 & 0.87 & 7 \\
\hline Industrial Bank & 1.00 & 1.00 & 1.00 & 1.00 & 1.00 & 1.00 & 1.00 & 1.00 & 1 \\
\hline Minsheng Bank & 1.00 & 0.96 & 1.00 & 1.00 & 1.00 & 0.96 & 1.00 & 0.99 & 5 \\
\hline Merchants Bank & 0.82 & 1.00 & 1.00 & 1.00 & 1.00 & 1.00 & 1.00 & 0.97 & 6 \\
\hline Average & 0.82 & 0.81 & 0.72 & 0.86 & 0.85 & 0.87 & 0.92 & 0.83 & \\
\hline
\end{tabular}

Table 2 shows the 14 commercial banks pure innovation efficiency results. Jiujiang Bank's 
comprehensive innovation efficiency is only 0.51, and its pure innovation efficiency is1, indicating that its scale efficiency is less than1. Agricultural Bank of pure innovation efficiency ranking is still located in the bottom position of 14 banks, and its pure innovation efficiency is very low.

\subsection{Dynamic analysis of innovation efficiency based on Malmquist Index}

In order to analyze the trend of innovation efficiency of 14 commercial banks, this paper uses Malmquist index model to make up the static DEA model which cannot analyze the panel data.

Table 3-Annual M Index of Chinese 14 Commercial Banks and Its Decomposition Table

\begin{tabular}{|c|c|c|c|c|c|}
\hline & $\begin{array}{l}\text { Technical } \\
\text { efficiency } \\
\text { index }\end{array}$ & $\begin{array}{l}\text { Technical } \\
\text { progress } \\
\text { index }\end{array}$ & $\begin{array}{l}\text { Pure technical } \\
\text { efficiency } \\
\text { index }\end{array}$ & $\begin{array}{l}\text { Scale } \\
\text { efficiency } \\
\text { index }\end{array}$ & $\begin{array}{l}\text { Total Factor } \\
\text { Productivity } \\
\text { Index }\end{array}$ \\
\hline Bank of Shanghai & 1.149 & 1.133 & 1.141 & 1.007 & 1.302 \\
\hline Bank of Jiangsu & 1.067 & 1.121 & 1.045 & 1.021 & 1.196 \\
\hline Bank of Nanjing & 0.982 & 1.134 & 1.000 & 0.982 & 1.114 \\
\hline Bank of Ningbo & 0.998 & 1.090 & 0.965 & 1.034 & 1.087 \\
\hline Bank of Hangzhou & 0.947 & 1.152 & 1.000 & 0.947 & 1.091 \\
\hline Bank of Jiujiang & 0.867 & 1.025 & 1.000 & 0.867 & 0.889 \\
\hline Bank of China & 0.978 & 1.069 & 1.000 & 0.978 & 1.046 \\
\hline Agricultural Bank & 1.005 & 1.070 & 1.028 & 0.978 & 1.075 \\
\hline Construction Bank & 1.000 & 1.076 & 1.000 & 1.000 & 1.076 \\
\hline Guangfa Bank & 1.086 & 1.167 & 1.062 & 1.023 & 1.267 \\
\hline CITIC Bank & 1.087 & 1.138 & 1.084 & 1.003 & 1.238 \\
\hline Industrial Bank & 1.000 & 1.139 & 1.000 & 1.000 & 1.139 \\
\hline Minsheng Bank & 1.000 & 1.162 & 1.000 & 1.000 & 1.162 \\
\hline Merchants Bank & 1.035 & 1.130 & 1.035 & 1.000 & 1.170 \\
\hline Average & 1.012 & 1.114 & 1.025 & 0.988 & 1.128 \\
\hline
\end{tabular}

Overall, Total factor productivity TFP of 14 commercial banks is greater than1, with an average annual growth rate of $12.8 \%$ from 2009 to 2015. During this period, the level of innovation of commercial banks in China has improved. Joint-stock commercial banks TFP grew at an average annual rate of $19.5 \%$, higher than $11.3 \%$ of urban commercial banks and $6.6 \%$ of state-owned commercial banks. In recent years, in the fierce competition with large commercial banks and Internet finance, the joint-stock commercial banks have made breakthroughs in business innovation and diversification innovation. The growth rate of the joint-stock commercial banks is the highest growth rate of $26.7 \%$; the fastest growing city commercial banks in Shanghai Bank, the average annual growth rate of 30.2\%; state-owned commercial banks in the average annual the slowest growth rate was only $4.6 \%$.

TFP growth of commercial banks is driven by technological progress, technological progress, the average annual growth rate of $11.4 \%$, joint-stock banks, city firms, state-owned banks 
were $14.7 \%, 10.9 \%, 7.2 \%$. The technical efficiency level of commercial banks is only 1.012 . the average annual growth rate is $1.2 \%$. Although the annual growth rate is relatively small, commercial banks are still growing year by year.

\section{The analysis of the impact of internet financial development on the innovation efficiency of commercial banks}

\subsection{Influencing factors}

In order to analyze the influence of Internet financial development on the innovation efficiency of commercial banks, considering the efficiency of DEA-BCC model, the value range is between 0 and 1 , and the value is cut off at 0 . In this paper, the Tobit model is established on the basis of DEA analysis. Based on the comprehensive innovation efficiency of 14 commercial banks as the dependent variable, this paper constructs the Tobit model with the Internet finance, the scale of the bank assets, the traditional business income and the holding nature as the independent variables. The Tobit model is as follows:

$$
y_{i t}^{*}=\alpha_{i}+\beta_{1} \operatorname{InINF}_{i t}+\beta_{2} \operatorname{InA}_{i t}+\beta_{3} \operatorname{InCAR}_{i t}+\beta_{4} \operatorname{InFE}_{i t}+\beta_{5} \operatorname{InII}_{i t}+\beta_{6} H A_{i t}+\varepsilon_{i t}
$$

This paper will select the third party payment and P2P transaction size as the representative of Internet finance. The meaning of the variables is shown in Table 4:

Table 4-Influencing factor variable definition table

\begin{tabular}{|c|c|c|c|}
\hline Variable name & & Symbol & Variable definitions \\
\hline $\begin{array}{l}\text { Explained } \\
\text { variable }\end{array}$ & Innovation efficiency & IE & $\begin{array}{l}\text { The efficiency of bank innovation based on } \\
\text { BCC model }\end{array}$ \\
\hline $\begin{array}{l}\text { Explanatory } \\
\text { variables }\end{array}$ & Internet Finance & INF & $\begin{array}{l}\text { Third party payment and P2P network loan } \\
\text { total transaction size }\end{array}$ \\
\hline & Bank asset size & A & The total assets of the bank \\
\hline Control & Capital adequacy ratio & CAR & $\begin{array}{c}\text { The ratio of total bank capital to weighted risk } \\
\text { assets }\end{array}$ \\
\hline \multirow[t]{3}{*}{ variable } & Management costs & FE & The current management cost of the bank \\
\hline & Innovation income & II & Bank intermediary business income \\
\hline & Holding nature & HA & virtual variable \\
\hline
\end{tabular}

\subsection{Tobit regression analysis}

Stata 13.1 software is used for Tobit regression analysis in this paper, the specific results are shown in Table 5. 
Table 5- The Analysis of the Impact of Internet Financial Development on the Innovation Efficiency of Commercial Banks

\begin{tabular}{lllll}
\hline Variables & Coef & Std.Err & $\mathrm{z}$ & $\mathrm{P}>|\mathrm{z}|$ \\
\hline LnINF & $-0.099^{*}$ & 0.056 & -1.77 & 0.076 \\
InA & $0.046^{* *}$ & 0.019 & 2.48 & 0.013 \\
CAR & $0.037^{* *}$ & 0.017 & 2.13 & 0.033 \\
InFE & $-0.258^{* * *}$ & 0.060 & -4.26 & 0.000 \\
LnII & $0.337^{* * *}$ & 0.047 & 7.15 & 0.000 \\
HA & $-0.403^{* * *}$ & 0.089 & -4.52 & 0.000 \\
cons & 0.874 & 0.682 & 1.28 & 0.200 \\
\hline
\end{tabular}

The explanatory variable coefficient of Internet financial transaction is -0.099 , and it is significant at $10 \%$ level, which shows that the development of Internet finance has a significant negative impact on the efficiency of commercial banks' comprehensive innovation. With the development of Internet finance, commercial bank innovation Efficiency is declining. The business income of commercial banks is affected by the financial development of the Internet, and thus force it to carry out the innovation of the business and service types to a certain extent, but it takes some time to promote new business and service types.

The explanatory variable coefficient of bank assets is 0.046 , and it is significant at $5 \%$ level, which indicates that the scale of bank assets has a significant positive impact on the innovation efficiency of commercial banks. The explanatory variable coefficient of capital adequacy ratio is 0.037 , and it is significant at $5 \%$ level, which indicates that the capital adequacy ratio has a significant positive impact on the innovation efficiency of commercial banks. The explanatory variable coefficient of bank management cost is -0.258 , and it is significant at $1 \%$ level, which shows that the cost of bank management has a significant negative impact on the innovation efficiency of commercial banks. The explanatory variable coefficient of bank's innovation income is 0.337 , and it is significant at $1 \%$ level, which shows that the innovation income of commercial banks has a significant positive impact on the innovation efficiency of commercial banks. The explanatory variable coefficient for holding properties is -0.403 and is significant at the $1 \%$ level. It shows that state-owned large banks have a significant negative impact on the efficiency of comprehensive innovation of commercial banks compared with non-state banks. In terms of changes in the financial environment, non-state banks have better resilience and resilience than state-owned banks, and have a higher lead in innovation efficiency.

\section{Conclusion and suggestion}

Overall, it is found that the comprehensive innovation efficiency of commercial banks is high, but the innovation efficiency gap between urban commercial banks, state-owned banks and 
joint-stock commercial banks is obvious. Through the analysis of Malmquist index, the growth rate of TFP in 14 commercial banks is more than1, the average annual growth rate is $12.8 \%$. Based on the analysis of the impact of Internet financial development on the innovation efficiency of commercial banks, it is found that with the rapid development of Internet finance, the innovation efficiency of commercial banks has been significantly affected negatively.

Commercial banks need to improve innovation efficiency from talent, product, technology, management and organization. Firstly, commercial banks should take the initiative to tap, cultivate innovative talents, the establishment of an open innovation sector, increase investment in the innovation sector. Secondly, commercial banks should actively develop new financial products, explore new financial services, customization of personalized products for special customers, especially the "long tail customers." Thirdly, commercial banks should strengthen technological innovation, grasp the development opportunities of block chain technology, and actively set up relevant organizations or alliances, strengthen the exchange of financial interbank and block industry applications. Banks can absorb learning and use of Internet technology to promote the efficiency of financial services for a significant increase. Finally, commercial banks should also strengthen management innovation, comprehensively improve the management level, reduce costs, pay attention to improve the existing funds, personnel, institutions and other inputs utilization.

\section{References}

1. Berger, A.N. and DeYoung, R, Problem Loans and Cost Efficiency in Commercial Banks, J. Journal of Banking and Finance. 21(1997) 849-870.

2. Bernstein, J, Asset Quality and Scale Economies in Banking, J. Journal of Economies and Business. 48(1990)157-166.

3. Li Wenliang, Research on the Relationship between Internet Finance and Commercial Bank's Innovation Performance - Based on MOA Theory, J. Finance Theory and Practice. 02(2017) 42-46.

4. Tan Zhengxun, Tuo Mingxuan, Non-performing loans, capital adequacy ratio and commercial bank efficiency, J. Finance Forum. 10(2016)40-50.

5. Xiang Xiaodong, Research on Efficiency Evaluation of China's Commercial Banks Based on Network DEA Cross Efficiency Model, J. Industrial Technology \& Economy. 02(2017)34-42.

6. Chen Jiaxin, Wang Jiankang, The impact of the balance of Internet financial products on commercial banking business - based on the analysis of event analysis, J. Economic issues. 01(2016)167-173.

7. Han Hongwen, Based on the dualism perspective analysis of Internet finance and commercial banks common development issues, J. Modern management science. 02(2017)118-120. 